\title{
Life-based financial literacy book as a teaching solution in the era of the COVID-19 pandemic
}

\section{Life-based financial literacy book sebagai solusi mengajar di era pandemi COVID-19}

\author{
Syahrul Munir, Agung Haryono, Sri Handayani, Yogi Dwi Satrio \\ Departemen Pendidikan Ekonomi, Fakultas Ekonomi, Universitas Negeri Malang \\ Jl. Semarang No.5 Malang, 65145, Malang, Indonesia
}

\begin{abstract}
ARTICLE INFO
Received: 2021-01-24

Revised: 2021-03-26

Accepted: 2021-05-02

Keywords:

Financial literacy,

Life-based,

Implementation

\section{ABSTRACT}

Nowadays, the problem of teachers in Economics is how a teacher should teach not only cognitive abilities but the ability to apply Economics in daily life. This community service program aims to provide skills for Economics teachers in teaching financial literacy to students. The method of implementation in this activity is training and mentoring in the implementation of financial literacy books. This program is intended for Economics/Accounting teachers at MGMP Malang City. This program was carried out in four stages, namely socialization and discussion, implementation of problem solving, training and mentoring, and evaluation. The implementation of this life-based "financial literacy" book provides insight to teachers about the implementation of financial literacy and learning innovations that can be applied to Economics learning in schools in the future. This activity is a forum for the development of learning innovations in the Economics/Accounting Subject Teacher Community or Musyawarah Guru Mata Pelajaran (MGMP).
\end{abstract}

(C)2021 Published by University of Merdeka Malang. This is an open access article distributed under the CC BY-SA 4.0 license (https://creativecommons.org/licenses/by-sa/4.0/)

How to cite: Munir, S., Haryono, A., Handayani, S., \& Satrio, Y, D. (2021). Life-based financial literacy book as a teaching solution in the era of the COVID-19 pandemic. Abdimas: Jurnal Pengabdian Masyarakat Universitas Merdeka Malang, 6(4), 491-502. https://doi.org/10.26905/abdimas.v6i4.5349

\section{PENDAHULUAN}

Aktivitas ekonomi modern berkembang secara cepat, seiring dengan perkembangan teknologi dan informasi. Untuk itu, masyarakat dituntut mampu mengambil keputusan ekonomi yang tepat dalam waktu yang singkat. Kemampuan ini merupakan bagian kompetensi yang dimiliki oleh seseorang pada bidang literasi keuangan, yaitu kemampuan mengelola aset dengan mempertimbangkan kemanfaatan dan biaya serta outcome dari setiap keputusan yang dibuat (Bosshardt \& Walstad, 2014).

Otoritas Jasa Keuangan (2017) merilis hasil survei literasi keuangan masyarakat Indonesia tahun 2016 masih rendah, yaitu 29,66\%. Selain itu, ditengarahi ada perbedaan tingkat literasi keuangan masyarakat di kota dan desa. Indeks literasi keuangan tertinggi terjadi di DKI Jakarta mencapai 40\%, 
ABDIMAS: Jurnal Pengabdian Masyarakat Universitas Merdeka Malang Volume 6, No. 4, November 2021: 491-502

diikuti oleh Jawa Barat 38,70\%, Daerah Istimewa Yogyakarta 38,55\%, Banten 38,18\%, Bali 37,45\%, dan Jawa Timur 35,58. Indeks literasi keuangan terendah terjadi di Papua Barat dengan angka 19,27\%, Nusa Tenggara Barat (NTB) 21,45\%, Papua 22,18\%, Sulawesi Tengah 22,55\%, serta Kalimantan Selatan dan Gorontalo sebesar 23,27\%.

Pendidikan diharapkan dapat menghasilkan sumber daya manusia yang berkualitas dan tangguh dalam menghadapi berbagai tantangan dan tuntutan termasuk dalam pengelolaan keuangan. Namun, kondisi empiris proses pembelajaran ekonomi di sekolah belum menyenangkan siswa. Siswa terlalu banyak dibebani tugas-tugas yang kurang bervariasi, seperti tugas-tugas lewat Lembar Kerja Siswa (LKS) dengan metode pembelajaran diskusi. Kondisi ini membuat siswa kurang tertarik terhadap pelajaran ekonomi, sehingga motivasi belajar siswa menjadi rendah (Haryono, 2013).

Fenomena di sekolah ada kecenderungan bahwa sekolah dikatakan berkualitas jika lulusannya memiliki kualitas akademis dan non akademis yang bagus. Prestasi akademis antara lain: (1) Nilai ulangan umum bagus; (2) Nilai ujian akhir bagus (lokal/nasional); dan (3) Jumlah dan mutu lomba-lomba mata pelajaran yang dimenangkan. Sedangkan prestasi non akademis adalah prestasi bidang ekstrakurikuler. Implikasi dari kecenderungan pengukuran keberhasilan sekolah dengan prestasi akademik siswa khususnya pada kemampuan koginitif, telah mendorong pengelola sekolah untuk mengejar prestasi itu dengan segala cara. Sekolah memacu kemampuan kognitif siswa seperti dengan memberi pelajaran tambahan, menggunakan metode drill dengan tujuan siswa pada mata pelajaran yang di UANkan mendapat nilai tinggi. Kondisi ini didukung oleh orang tua siswa, para orang tua tidak menginginkan putra-putrinya gagal di sekolah hanya karena kurang menguasai materi pelajaran yang di UAN-kan. Mata Pelajaran Ekonomi di SMA termasuk mata pelajaran yang di UAN-kan, dimana mayoritas soal UAN hanya mengukur kemampuan kognitif. Kondisi ini berdampak pada siswa dalam mempelajari ekonomi hanya mengutamakan penguasaan pengetahuan dibanding dengan implikasi terhadap sikap dan perilaku sehari-hari. Akibatnya siswa tidak dapat menerapkan pengetahuan ekonominya dalam kehidupan sehari-hari.

Guru sebagai elemen terdekat dengan siswa, tentunya harus tanggap menghadapi realita di lapangan ini. Guru hendaknya bisa mengarahkan siswa agar siswa dapat memiliki kemampuan tidak hanya sekedar kognitif saja namun kemampuan mengaplikasikan pengetahuan ekonomi yang dimiliki siswa di dalam kehidupan sehari-hari misalnya kemampuan dalam mengelola keuangan. Kemampuan seseorang dalam mengelola keuangan menjadi salah satu faktor penting untuk mencapai kesuksesan dalam kehidupan, sehingga pengetahuan akan pengelolaan keuangan yang baik dan benar menjadi sangat penting bagi masyarakat khususnya individu (Cummins, 2009).

Literasi keuangan merupakan pengetahuan dan pemahaman tentang konsep-konsep keuangan sehingga menghasilkan kemampuan untuk membuat keputusan yang efektif tentang uang (Capuano \& Ramsay, 2011; Remund, 2010). Pemahaman tentang pengelolaan keuangan ini sangatlah penting dan berguna bagi siswa dalam pengambilan keputusan yang benar dan positif terkait permasalahan keuangan, misalnya permasalahan berkaitan dengan penganggaran (budgeting), tabungan (saving), pinjaman (borrowing), dan investasi (investing) (Cude et al., 2006). Hal ini senada dengan apa yang diungkapkan oleh Widdowson \& Hailwood (2007) bahwa financial literacy akan mempengaruhi bagaimana orang dalam menabung, meminjam, berinvestasi, dan mengelola keuangan. 
Berdasarkan realita tersebut kemudian muncul ide untuk melakukan kegiatan pengabdian kepada masyarakat. Tujuan dari kegiatan pengabdian masyarakat ini secara khusus adalah untuk memberikan bekal kepada pada guru-guru Ekonomi di sekolah dalam mengajarkan tentang literasi keuangan yang tepat kepada siswa khususnya di masa pandemi seperti saat ini. Kegiatan ini merupakan implementasi dari pengembangan buku ajar "Finansial Literasi Berbasis Kehidupan" yang telah dikembangkan pada kegiatan penelitian sebelumnya. Kegiatan pengabdian ini nantinya diharapkan dapat memberikan dampak terhadap peningkatan kualitas proses pembelajaran siswa di sekolah, karena buku ajar yang diimplementasikan pada kegiatan pengabdian ini selain memiliki tujuan, materi, dan evaluasi juga dilengkapi model dan skenario pembelajaran inovatif yang bisa membantu guru dalam mengajarkan financial literacy.

Kegiatan pengabdian ini dilaksanakan di lingkungan Musyawarah Guru Mata Pelajaran (MGMP) Ekonomi/Akuntansi di Kota Malang. Permasalahan yang dihadapi oleh guru Ekonomi dalam MGMP Ekonomi/Akuntansi di Kota Malang saat ini adalah kebanyakan guru dalam mengajar hanya berorientasi pada pencapaian kemampuan kognitif siswa saja dan sangat sedikit sekali yang menyentuh hal-hal yang berkaitan dengan bekal kehidupan siswa sehari-hari misalnya tentang bagaimana mengelola keuangan dengan bijak. Kemampuan ini bisa diperoleh seandainya guru dapat mengajarkan tentang financial literacy dengan baik. Namun kenyataannya, tidak sedikit guru dalam mengajar hanya berorientasi pada pencapaian kemampuan yang menjadi tuntutan kurikulum semata.

Hal ini menjadi suatu permasalahan yang cukup serius, karena akan berpengaruh terhadap output siswa setelah lulus. Mereka hanya akan pandai dalam penguasaan konsep semata, tetapi kurang mampu dalam menerapkan ilmu yang diperoleh, misalnya tentang financial literacy. Materi ini akan sangat bermanfaaat bagi siswa jika guru dapat mengajarkannya dengan baik. Kenyataan di lapangan menunjukkan, kebanyakan guru saat ini masih belum mampu membekali siswa memiliki kemampuan dalam hal financial literacy.

Oleh sebab itu, para guru membutuhkan suatu cara yang tepat dalam membelajarkan materi tersebut, karena hal itu sangat diperlukan dalam kehidupan siswa sehari-hari. Permasalahan inilah yang kemudian membuat tim sepakat untuk melakukan kegiatan pengabdian masyarakat di lingkungan MGMP Ekonomi/Akuntansi Kota Malang untuk membelajarkan financial literacy sebagai implementasi dari pengembangan buku ajar yang dilaksanakan sebelumnya. Kegiatan pengabdian ini diharapkan akan menjadi sarana untuk meningkatkan kompetensi guru dalam pemahaman financial literacy beserta cara mengajarkannya untuk anak didik di kelas. Kegiatan ini akan menjadi solusi bagi kesulitan guruguru yang selama ini dialami dalam mengajarkan dan mengenalkan materi tersebut untuk anak didik di sekolah.

\section{METODE}

Pemecahan masalah yang dilakukan dalam kegiatan ini menggunakan metode pelatihan dan pendampingan. Tahapan-tahapan metode pelaksanaan kegiatan implementasi "Financial Literacy Book" dapat dilihat pada Gambar 1. 
ABDIMAS: Jurnal Pengabdian Masyarakat Universitas Merdeka Malang Volume 6, No. 4, November 2021: 491-502
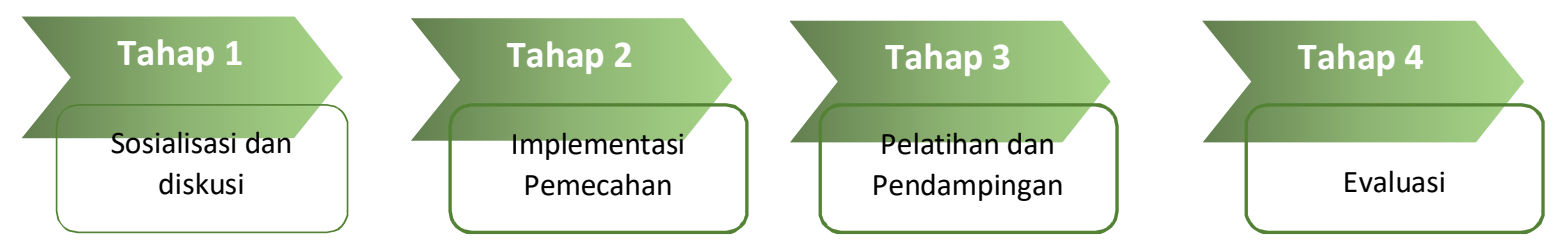

Gambar 1. Implementasi buku "Financial Literacy"

Pada Tahap 1, kegiatan pengabdian diawali dengan kegiatan sosialisasi dan diskusi dengan guru Ekonomi di lingkungan MGMP Ekonomi/Akuntansi Kota Malang. Hal ini dilakukan untuk menggali informasi tentang permasalahan yang terjadi di guru-guru Ekonomi/Akuntansi di lingkungan MGMP Ekonomi/Akuntansi Kota Malang. Selanjutnya, pada Tahap 2 setelah diperoleh informasi tentang masalah pembelajaran di lingkungan MGMP Kota Malang, barulah tim melakukan implementasi untuk memecahkan masalah tersebut. Pada tahap ini, dilakukan rencana implementasi untuk memecahkan masalah yang diperoleh pada tahap sebelumnya.

Kemudian pada Tahap 3 dilaksanakan kegiatan implementasi kegiatan berupa pelatihan dan pendampingan. Kegiatan ini dilakukan dalam beberapa langkah. Kegiatan pelatihan tentang implementasi "Financial Literacy Book" berbasis kehidupan dilakukan dengan terlebih dahulu memberikan pemahaman konsep financial literacy dan cara mengajarkannya pada siswa melalui kegiatan ceramah dan pemberian contoh-contoh model pengajarannya. Tim memberikan ilustrasi dan contoh-contoh materi dari buku kemudian menunjukkan cara mengaplikasikannya dalam pembelajaran menggunakan model-model pembelajaran yang sesuai. Gambar 2 merupakan contoh sub-materi financial literacy yang dijelaskan dengan inovasi pembelajaran studi kasus (case study) dan penemuan (discovery learning).

Pada sub-materi ini, tim memberikan contoh cara membelajarkan materi tersebut menggunakan studi kasus (case study) dan penemuan (discovery learning). Pembelajaran ini dipilih sebagai Inovasi pembelajaran yang bisa diaplikasikan oleh guru MGMP Ekonomi/Akuntansi Kota Malang dalam mengajarkan materi ini. Dari informasi yang diperoleh tim, bahwa guru selama ini mengajarkan materi ini hanya dengan penanaman konsep saja sehingga siswa memahami materi tersebut hanya dalam tataran konsep saja. Melalui kegiatan ini, guru dibuka wawasannya untuk mengajarkan materi tersebut dengan seinovatif mungkin agar tujuan pembelajaran dapat tercapat dengan baik.

Kemudian dilanjutkan dengan praktik mengimplementasikan "Financial Literacy Book". Praktik pengaplikasian "Financial Literacy Book" dilakukan dengan cara simulasi dan pendampingan oleh tim pelaksana kegiatan pengabdian masyarakat. Simulasi oleh tim dilakukan dengan pemberian contoh kasus sesuai dengan materi yang ada di "Financial Literacy Book" kepada guru-guru, kemudian guru mencoba mengelaborasi dari apa yang telah dijelaskan oleh tim dan menjadikan informasi yang diperoleh sebagai referensi dalam melaksanakan tugas mengajar. Tim melakukan pendampingan terhadap guru dalam memahami "Financial Literacy Book" dengan menerapkan berbagai metode inovatif.

Langkah selanjutnya adalah simulasi mengimplementasikan "Financial Literacy Book". Tim mendampingi guru-guru melakukan implementasi dengan memberikan inovasi pembelajaran yang dikaitkan dengan perkembangan teknologi informasi dan komunikasi. Pada tahapan ini guru 
melakukan implementasi "Financial Literacy Book" menggunakan laptop/handphone sebagai sarana pembelajaran. Berbeda dengan tahapan sebelumnya, dimana guru diajak menganalisis kasus namun hanya berupa simulasi verbal tanpa menggunakan laptop/handphone. Pada tahapan ini, guru diajak memanfaatkan laptop/handphone dan berbagai macam software yang relevan guna mendukung kegiatan pembelajaran. Kegiatan ini dilakukan untuk menumbuhkan semangat guru dalam mengajar di era pandemi yang mengharuskan pembelajaran dilakukan secara online. Tim juga mengenalkan para guru dengan beberapa pembelajaran online yang bisa membantu guru di saat pandemi seperti sekarang ini. Pembelajaran online tersebut misalnya pembelajaran berbasis permainan (gamification), pembelajaran menggunakan Paddlet, pembelajaran menggunakan Mentimeter, dan lain sebagainya. Pembelajaran online ini dipraktikkan di depan para guru di MGMP, yang nantinya guru akan diminta untuk mempraktikkan atau mencobanya di laptop masing-masing sambil di dampingi oleh tim. Gambar 3 menunjukkan tim sedang melakukan simulasi aplikasi Paddlet yang ditayangkan pada layar monitor.

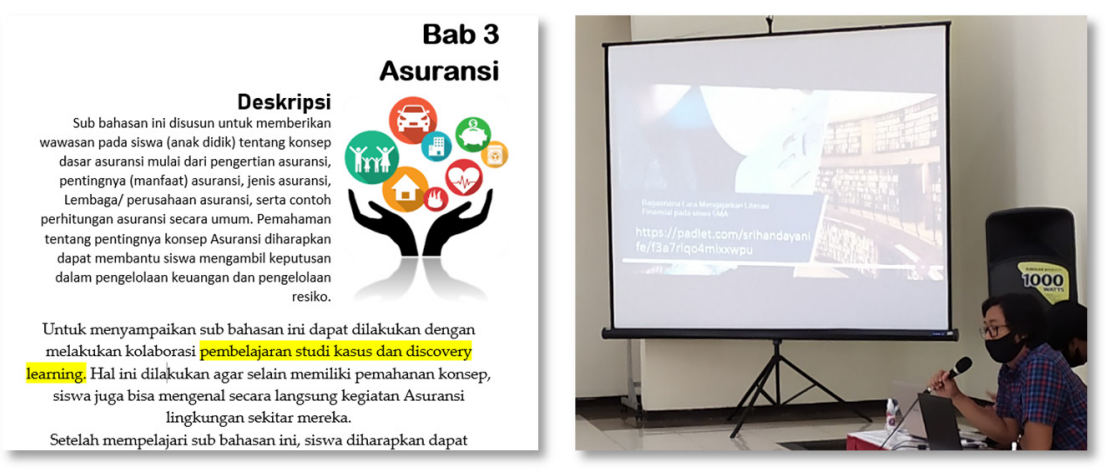

Gambar 2. Contoh inovasi pembelajaran pada sub-materi asuransi

Gambar 3. Simulasi aplikasi Paddlet

Pada simulasi yang ditampilkan Gambar 3 tersebut, tim mencontohkan langkah-langkah dalam penggunaan Paddlet, serta menunjukkan manfaat yang bisa dilakukan dalam menjelaskan materi di saat pembelajaran daring. Fitur-fitur yang bisa dipakai juga turut dijelaskan dalam simulasi tersebut. Pada kegiatan tersebut, peserta juga diperkenankan untuk menanyakan hal-hal yang barangkali belum dimengerti oleh para guru. Setelah tim melakukan simulasi dengan berbagai inovasi pembelajaran dengan menggunakan pembelajaran online, kemudian para guru diberikan kasus dan diminta untuk menyelesaiankannya menggunakan contoh pembelajaran online yang telah disimulasikan pada tahap sebelumnya. Pembelajaran online tersebut antara lain pembelajaran berbasis permainan (gamification), pembelajaran menggunakan Paddlet, dan pembelajaran menggunakan Mentimeter. Pada kegiatan ini, tim mendampingi proses penyelesaian kasus yang diberikan pada guru dengan sesekali mengulangi langkah-langkah penyelesaiannya jika para guru menemui kesulitan. Tim mendampingi guru-guru yang masih belum terlalu menguasai pembelajaran daring. Penjelasan dilakukan menyesuaikan dengan pemahaman para guru terkait pembelajaran daring.

Hasil implementasi dari kegiatan pelatihan dan pendampingan ini kemudian dipraktikkan oleh guru-guru MGMP di sekolah masing-masing, kemudian guru melaporkan hasil kegiatan tersebut kepada 
ABDIMAS: Jurnal Pengabdian Masyarakat Universitas Merdeka Malang Volume 6, No. 4, November 2021: 491-502

tim pelaksana kegiatan pengabdian. Pada saat pelaksanaan di sekolah, guru-guru tetap berkoordinasi dengan tim pelaksana kegiatan pengabdian pada masyarakat. Guru melakukan implementasi "Financial Literacy Book" dengan memanfaatkan inovasi pembelajaran daring yang telah dijelaskan oleh tim. Guru menyesuaikan materi financial literacy dengan sajian materi yang sedang berlangsung di sekolah masing-masing.

Tahap akhir dari pelaksanaan kegiatan pengabdian ini adalah melakukan evaluasi dari apa yang telah dilakukan dalam kegiatan implementasi. Tahap evaluasi dilakukan oleh tim pelaksana kegiatan dibantu oleh tim lapangan. Kegiatan evaluasi ini dilakukan untuk memberikan feedback dari kegiatan yang telah dilaksanakan. Feedback ini akan digunakan sebagai bahan masukan dan perbaikan untuk kegiatan selanjutnya. Kegiatan evaluasi ini juga dapat digunakan bahan masukan untuk para guru di MGMP Ekonomi/Akuntansi Kota Malang terkait dengan perkembangan pembelajaran. Gambaran dalam kegiatan evaluasi yang dirancang dalam kegiatan ini disajikan dalam Tabel 1.

Tabel 1. Pedoman evaluasi

\begin{tabular}{lll}
\hline \multicolumn{1}{c}{ Tujuan } & \multicolumn{1}{c}{ Indikator Ketercapaian } & \multicolumn{1}{c}{ Tolok Ukur } \\
\hline $\begin{array}{l}\text { Peserta memiliki minat dan motivasi } \\
\text { untuk mengajarkan materi literasi } \\
\text { keuangan }\end{array}$ & $\begin{array}{l}\text { Minat dan motivasi peserta dalam meng- } \\
\text { ajarkan materi literasi keuangan menjadi } \\
\text { meningkat }\end{array}$ & $\begin{array}{l}\text { Peserta mau menyadari arti pen- } \\
\text { tingnya mengajarkan mata pelajaran } \\
\text { ekonomi khususnya materi financial } \\
\text { literacy }\end{array}$ \\
$\begin{array}{l}\text { Peserta mampu mengajarkan literasi } \\
\text { keuangan pada siswa dengan baik }\end{array}$ & $\begin{array}{l}\text { Peserta telah mampu memahami isi buku } \\
\text { tentang financial literacy dengan baik }\end{array}$ & $\begin{array}{l}\text { Peserta memiliki pedoman dalam } \\
\text { mengajar materi financial literacy }\end{array}$ \\
\hline
\end{tabular}

\section{HASIL DAN PEMBAHASAN}

Inovasi pembelajaran berbasis kehidupan pada prinsipnya adalah mengajar peserta didik sesuai dengan lingkungan dan tuntutan kehidupan. Beberapa model pembelajaran yang menggunakan setting kehidupan nyata sudah dilakukan pada berbagai jenjang pendidikan. Hasil penerapan dari model ini dilaporkan bahwa mahasiswa sangat antusias dan ketergantungan antar mahasiswa telah mendorong untuk belajar lebih giat sehingga hasilnya menjadi lebih baik.

Implementasi "Financial Literacy Book" berbasis kehidupan yang dikemas dalam kegiatan pengabdian pada masyarakat ini merupakan semangat dari penerapan inovasi pembelajaran berbasis kehidupan. Dengan melakukan implementasi "Financial Literacy Book" yang berbasis kehidupan ini, diharapkan dapat memberikan wawasan pada guru tentang inovasi pembelajaran dan nantinya dapat diterapkan pada pembelajaran Ekonomi di sekolah masing-masing. Kegiatan pengabdian pada masyarakat ini adalah sebuah upaya dalam menjalin sinergi dan komunikasi antara pendidik di lingkup Universitas Negeri Malang dengan para pendidik (guru) Ekonomi di tingkat sekolah Menengah, khususnya di lingkungan MGMP Ekonomi/Akuntansi di Kota Malang.

Kegiatan pengabdian ini ditujukan untuk peningkatan kualitas dan peran guru di dalam melaksanakan tugas sebagai pendidik. Hal ini sebagaimana yang diungkapkan oleh Nurhadi (1996) bahwa dalam rangka meningkatkan peran dan kualitas guru dapat dilakukan dengan berbagai cara antara lain: (1) Guru tidak hanya menguasai bidang studinya, tetapi menguasai IPTEKS yang memadai 
dan mengintegrasikannya ke dalam bidang studi yang diajarkan; (2) Sejak dini guru perlu mananamkan nilai budaya masyarakat industri kepada peserta didik; (3) Mengintensifkan intervensi guru dalam rangka mendorong anak sadar dan mau bersekolah; (4) Membantu anak dalam mencari sumber informasi yang memungkinkan anak menguasai IPTEK; (5) Memberi kesempatan guru untuk studi lanjut; (6) Memperbaiki insentif guru; (7) Ada perbaikan sistem pengangkatan kepala sekolah; dan (8) Penyesuaian jenjang pendidikan dengan kebutuhan dan kemajuan IPTEK bagi guru dan calon guru. Inti kegiatan pengabdian ini berada pada tahap 3 dari semua tahapan yang ada dalam metode pelaksanaan kegiatan pengabdian. Pada tahap 3 dilakukan kegiatan implementasi berupa kegiatan pelatihan dan pendampingan dalam memanfaatkan "Financial Literacy Book" dengan berbagai metode dan inovasi pembelajaran yang mendukung di era saat ini.

Kegiatan pelatihan dan pendampinan ini diawali dengan melakukan penyamaan persepsi dan pemberian penguatan materi tentang pentingnya financial literacy pada siswa SMA oleh ketua tim yaitu Dr. Agung Haryono, SE., M.P., Ak. Hal ini sangat penting untuk disampaikan agar guru dapat memiliki bekal yang kuat dalam menyampaikan materi kepada siswa. Hal yang diharapkan adalah terjadi perbaikan dan inovasi dalam pembelajaran di kelas dan semakin menambah profesionalitas para guru dalam mengajar di sekolah. Perbaikan kualitas pembelajaran ekonomi dapat berkontribusi dalam perbaikan kualitas pendidikan. Kegiatan pembelajaran akan dikatakan berkualitas jika proses pembelajaran dilaksanakan secara efektif dan efisien serta dapat memberikan dampak yang positif sehingga tercapai tujuan pembelajaran (Mulyasa, 2011). Pada Gambar 4 ditunjukkan kegiatan pemaparan materi oleh ketua tim pelaksana pengabdian masyarakat.

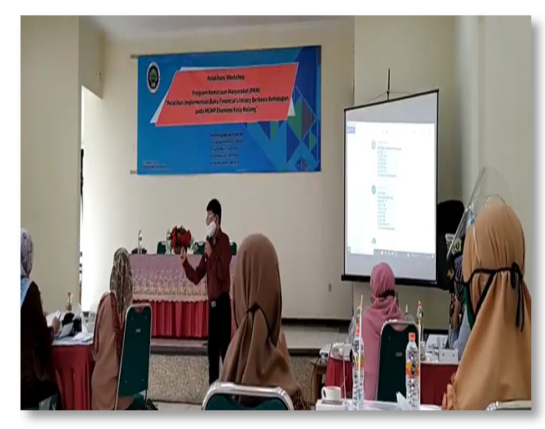

Gambar 4. Pemaparan materi dengan metode life-based learning

Pemaparan materi dilakukan dengan melakukan interaksi dengan para guru MGMP. Para guru diajak membicarakan sebuah kasus di kehidupan sehari-hari terkait masalah financial literacy. Dari kegiatan tersebut, guru diberikan penjelasan bahwa kasus kehidupan nyata yang disajikan tersebut adalah bagian dari konten buku yang dapat dipelajari oleh guru dan siswa di sekolah. Konten buku financial literacy yang dikemas berbasis kehidupan ini diharapkan dapat membantu guru dan siswa dalam mengenali dan menyikapi masalah financial literacy di kehidupan sehari-hari secara bijak. Pembelajaran yang berbasis pada kehidupan yang ada dalam buku ini, diharapkan dapat membantu siswa agar bisa 
ABDIMAS: Jurnal Pengabdian Masyarakat Universitas Merdeka Malang Volume 6, No. 4, November 2021: 491-502

bertahan dalam era baru seperti saat ini yaitu era yang komoditas utamanya adalah ilmu pengetahuan itu sendiri (Hambali, 2017).

Disamping pemaparan materi tentang financial literacy, dalam kegiatan pengabdian juga disampaikan materi tentang metode pembelajaran inovatif yang mendukung implementasi "Financial Literacy Book" di sekolah. Metode pembelajaran inovatif tersebut masuk di dalam tiap sub-materi yang ada di buku, sehingga dapat menjadi masukan saat guru mengajar. Pada tahap ini tim juga menunjukkan bagaimana cara mengajarkan materi menggunakan beberapa pembelajaran inovatif, misalnya studi kasus (case study), pembelajaran penemuan (discovery learning), dan lain-lain.

Para guru di sekolah dapat menyesuaikan materi pelajaran yang diajarkan dengan metode pembelajaran inovatif yang saat ini sedang berkembang, khususnya pada saat kondisi pandemi. Sebagaimana telah diketahui bersama bahwa pembelajaran di era pandemi sebagian besar adalah pembelajaran secara online (daring). Pembelajaran daring sangat dibutuhkan dalam pembelajaran di era revolusi industri 4.0 dan di era pandemi seperti saat ini (Pangondian et al., 2019).

Pembelajaran inovatif yang sedang dipaparkan dalam kegiatan pengabdian ini antara lain pembelajaran metode life-based dengan memanfaatkan aplikasi Mentimeter, Paddlet, gamification, dll. Guru sangat antusias mengikuti pemaparan tentang pembelajaran inovatif tersebut, karena para guru sangat membutuhkan variasi pembelajaran di saat kondisi pembelajaran dilakukan secara online (daring). Berbagai inovasi pembelajaran ini akan menjadi referensi para guru untuk mengajar materi ekonomi dengan tingkat kesulitan materi yang berbeda-beda.

Berbagai macam pembelajaran inovatif tersebut adalah solusi pembelajaran yang dapat digunakan dalam belajar secara daring (online) atau masa pandemi, dan juga dimanfaatkan untuk mengimplementasikan "Financial Literacy Book". Para guru MGMP Ekonomi/Akuntasi Kota Malang sangat responsif terhadap perkembangan pembelajaran. Para guru sangat antusias dan tertarik untuk belajar dan mencoba inovasi pembelajaran yang sedang dijelaskan dalam kegiatan pengabdian ini.

Hal tersebut akan menjadi tambahan ilmu bagi guru yang nanti akan diterapkan di sekolah masing-masing, sehingga manfaat dan makna kegiatan ini akan sangat terasa di dalam kegiatan pembelajaran di sekolah. Inovasi pembelajaran yang diperoleh dari hasil pengabdian masyarakat ini adalah sebagian dari banyaknya strategi mengajar kognitif pada umumnya yang bisa diterapkan oleh guru di kelas (Djiwandono, 2006). Kegiatan pemaparan materi pada kegiatan pengabdian masyarakat tersebut ditunjukkan pada Gambar 5.
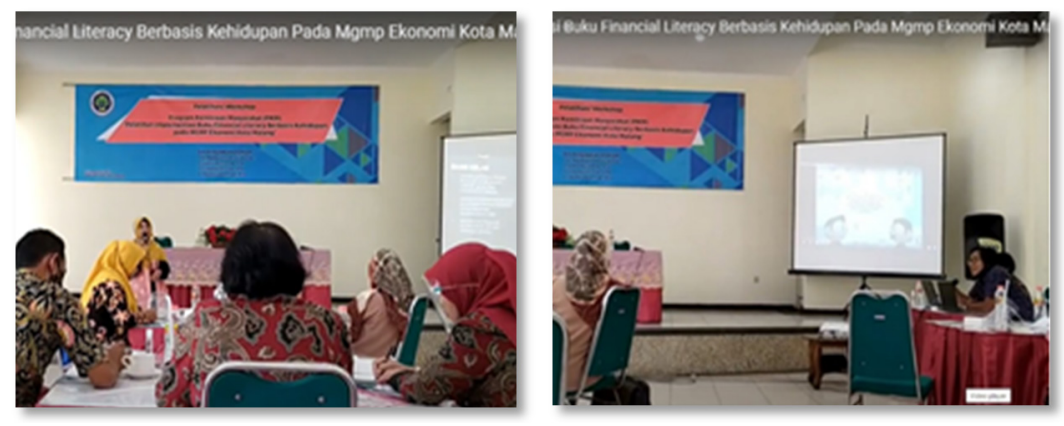

Gambar 5. Pemaparan pembelajaran inovatif life-based Financial Literacy Book 
Kegiatan implementasi "Financial Literacy Book" berbasis kehidupan ini memberikan manfaat yang positif terhadap guru-guru peserta kegiatan pengabdian masyarakat. Banyak hal yang diperoleh dari kegiatan ini, antara lain: (1) Para guru memperoleh tambahan pemahaman tentang konsep financial literacy dan pembelajaran berbasis kehidupan (life-based learning); (2) Para guru memperoleh tambahan pengetahuan tentang cara mengajarkan materi financial literacy dengan tepat berdasarkan kasus dikehidupan sehari-hari; (3) Para guru memperoleh informasi tentang pembelajaran inovatif yang dapat menambah profesionalisme guru; dan (4) Para guru juga memperoleh pemahaman tentang pembelajaran online (daring) yang menggunakan aplikasi-aplikasi baru yang bermanfaat dalam pembelajaran, misalnya aplikasi Paddlet, Mentimeter, gamafikasi, dan lain sebagainya.

Pada kegiatan pengabdian pada masyarakat ini, tim memberikan tambahan wawasan berupa pembelajaran online, salah satunya adalah aplikasi Paddlet. Sebagaimana yang telah kita ketahui bahwa Paddlet merupakan aplikasi web 2.0 yang sedang booming di samping aplikasi lainnya seperti Slideshare, Blendspace, Storybird, Voki, dan lain-lain. Paddlet bisa digunakan untuk mewadahi aktivitas seperti diskusi, curah pendapat, dan pengerjaan sebuah proyek (Stannard, 2015). Penggunaan aplikasi Paddlet dalam menjelaskan life-based financial literacy dalam pembelajaran daring ini memberikan banyak manfaat, salah satunya adalah memberi ruang kepada siswa untuk berkolaborasi (Dembo \& Bellow, 2013; Fuchs, 2014). Tampilan aplikasi Paddlet yang bisa menjadi variasi dalam pembelajaran disajikan pada Gambar 6.

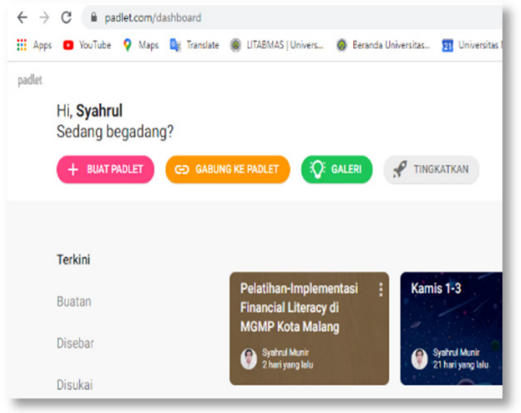

Gambar 6. Tampilan aplikasi Paddlet dalam Implementasi life-based Financial Literacy Book

Pembelajaran menggunakan Mentimeter juga akan membantu guru di MGMP Ekonomi/Akuntansi Kota Malang dalam pembelajaran online (daring). Pembelajaran menggunakan Mentimeter akan memberikan warna baru terhadap siswa. Dari sini, diharapkan siswa semakin tertarik dalam pembelajaran. Mentimeter merupakan aplikasi online yang berbasis website dan bisa digunakan oleh guru untuk mengajak siswa aktif menyampaikan pendapat dan interaksi secara real time. Pembelajaran dengan memanfaatkan Mentimeter juga dapat meningkatkan keterlibatan siswa dalam menyampaikan ide-ide, karena biasanya dengan menggunakan Mentimeter identitas siswa tidak ditampilkan sehingga siswa tidak malu untuk menyampaikan idenya pada materi tertentu (Mayhew, 2018). Gambar 7 adalah tampilan aplikasi Mentimeter yang dijelaskan dalam kegiatan pengabdian masyarakat, sebagai variasi pembelajaran inovatif di era pembelajaran daring. 
ABDIMAS: Jurnal Pengabdian Masyarakat Universitas Merdeka Malang Volume 6, No. 4, November 2021: 491-502

Berdasarkan hasil evaluasi dan laporan dari peserta kegiatan pengabdian masyarakat, diperoleh informasi bahwa kegiatan pengabdian ini tidak berhenti begitu saja sampai kegiatan pelatihan. Namun, materi dalam kegiatan ini setelah kegiatan pengabdian masyarakat diaplikasikan oleh para guru dalam kegiatan pembelajaran di sekolah masing-masing, yang mana pembelajarannya adalah selama ini menggunakan daring.

Hasil laporan tim pelaksana kegiatan, diperoleh informasi bahwa guru-guru di MGMP Ekonomi/ Akuntansi Kota Malang banyak yang sangat antusias untuk melaksanakan hasil pengabdian misalnya ibu guru dari SMA Islam Nusantara Malang, ibu guru dari SMA Darul 'Ulum Agung Malang, bapak guru SMA Negeri 2 Malang, dan lain-lain. Pada saat mengajar dalam pembelajaran daring bapak/ ibu guru mengimplementasikan konten Financial Literacy Book dalam pembelajaran. Para guru mengimplementasikan konten Financial Literacy Book menyesuaikan dengan materi yang diajar, misalnya pembahasan tentang uang, bank dan lembaga keuangan bukan bank, asuransi, dan pasar modal. Pada Gambar 8 memperlihatkan contoh guru menjelasakan materi financial literacy untuk materi uang, bank dan lembaga keuangan bukan bank.
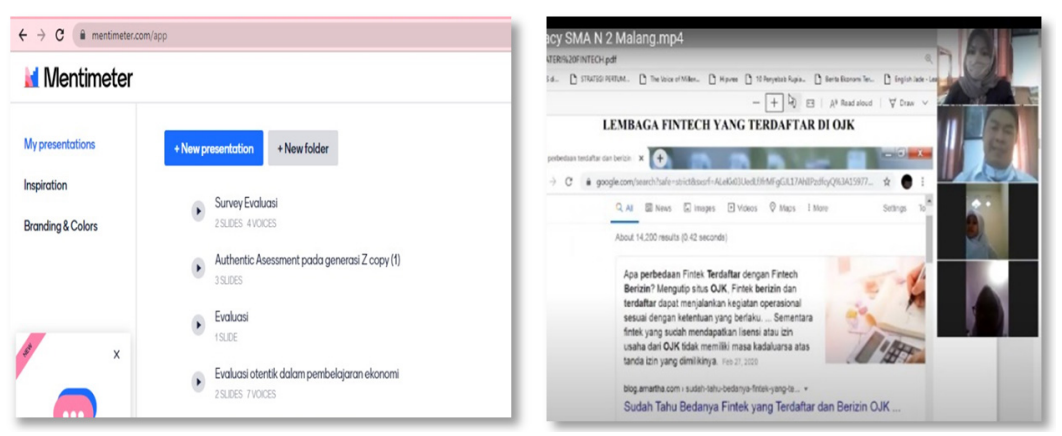

Gambar 7. Tampilan aplikasi Mentimeter dalam implementasi life-based Financial Literacy Book Gambar 8. Penerapan materi pengabdian di SMA 2 Negeri Malang

Kegiatan pengabdian pada masyarakat ini secara umum dapat dikatakan telah mencapai hasil baik sesuai dengan tujuan dan harapan kegiatan pengabdian. Dari pengabdian ini, selain dapat membantu menambah pemahaman guru dalam membelajarkan konsep financial literacy dengan berbagai metode inovatif seperti Paddlet, Mentimeter, dan gamafikasi, juga terjalinnya komunikasi yang baik antara lingkungan Universitas dengan para guru di sekolah khususnya lingkungan guru-guru di MGMP Ekonomi/Akuntansi. Keberhasilan kegiatan pengabdian ini adalah selain didukung oleh penyajian materi yang baik oleh tim, juga didukung oleh antusias para guru dalam mengikuti kegiatan. Selain itu, para guru juga serius untuk menerapkan hasil kegiatan pengabdian pada kegiatan pembelajaran di sekolah, sehingga ilmu yang diperoleh tidak berhenti sampai saat kegiatan pengabdian saja melainkan terus sampai pada anak didik disekolah. Hambatan yang dialami tim dalam kegiatan ini adalah bervariasinya kesibukan dari peserta membuat sedikit kesulitan menentukan waktu pelaksanaan kegiatan. Namun, peran ketua MGMP sangat membantu dalam penentuan waktu pelaksanaan kegiatan pengabdian masyarakat. 


\section{SIMPULAN DAN SARAN}

Pelaksanaan implementasi "Financial Literacy Book" di lingkungan MGMP Ekonomi/Akuntasi Kota Malang terlaksana dengan baik. Implementasi dilakukan dalam bentuk pelatihan mengaplikasikan konsep life-based pada pembelajaran financial literacy di sekolah dengan panduan "Life-based Financial Literacy Book" yang dikembangkan oleh tim pengabdian masyarakat dari Universitas Negeri Malang. Kegiatan pengabdian masyarakat ini dilakukan untuk kebutuhan pembelajaran daring dan tatap muka sehingga tim pelaksana menggunakan inovasi pembelajaran yang inovatif dalam pelaksanaannya. Kegiatan ini dapat terlaksana dengan baik, berkat kerjasama tim dan antusiasme peserta dalam kegiatan pengabdian pada masyarakat.

Perlu adanya kegiatan lanjutan yang berupa pelatihan dengan tema sejenis untuk diselenggarakan secara periodik sehingga dapat memberikan referensi pembelajaran yang inovatif dan menarik yang bisa diaplikasikan di dalam pembelajaran. Kegiatan pengabdian seharusnya dapat mendorong MGMP Ekonomi/Akuntansi Kota Malang yang solid dalam pemecahan masalah pembelajaran Ekonomi/ Akuntansi di Kota Malang.

\section{UCAPAN TERIMA KASIH}

Penulis mengucapkan terima kasih kepada Universitas Negeri Malang yang telah memberikan kesepatan kepada penulis untuk melakukan kegiatan pengabdian masyarakat ini sebagai bentuk dari kegiatan Tri Dharma Perguruan Tinggi. Penulis juga mengucapkan terima kasih kepada LP2M, Universitas Negeri Malang yang telah membantu pendanaan untuk pelaksanaan kegiatan penelitian ini melalui Hibah kompetitif Perguruan Tinggi di Universitas Negeri Malang. Ucapan terima kasih juga disampaikan Tim Pengabdian Masyarakat serta para peserta yaitu para guru Ekonomi/Akuntansi di lingkungan MGMP Ekonomi/Akuntansi Akuntasi Kota Malang.

\section{DAFTAR PUSTAKA}

Bosshardt, W., \& Walstad, W. B. (2014). National standards for financial literacy: Rationale and content. The Journal of Economic Education, 45(1), 63-70. https://doi.org/10.1080/00220485.2014.859963

Capuano, A., \& Ramsay, I. (2011). What causes suboptimal financial behaviour? An exploration of financial literacy, social influences and behavioural economics [Paper]. $U$ of Melbourne Legal Studies Research Paper No. 540. http://dx.doi.org/10.2139/ssrn.1793502

Cude, B. J., Lawrence, F. C., Lyson, A. C., Metzger, K., LeJeune, E., Marks, L., \& Machtmes, K. (2006). Collage student and financial literacy: What they know and what we need to learn. Eastern Family Economic and Resource Management Association.

Cummins, M. M., Haskell, J. H., \& Jenkins, S. J. (2009). Financial attitudes and spending habits of university freshmen. Journal of Economics and Economic Education Research, 10(1), 3-20. 
ABDIMAS: Jurnal Pengabdian Masyarakat Universitas Merdeka Malang Volume 6, No. 4, November 2021: 491-502

Dembo, S. E., \& Bellow, A. S. (2013). Untangling the web: 20 tools to power up your teaching. London: Corwin Press.

Djiwandono, S. E. W. (2006). Psikologi pendidikan. Jakarta: PT Gramedia

Fuchs, B. (2014). The writing is on the wall: Using Padlet for whole-class engagement. Loex Quarterly, 40(4), 7-9.

Haryono, A. (2013). Pengaruh persepsi proses pembelajaran, penilaian dan status sosial ekonomi terhadap literasi ekonomi siswa SMA. Jurnal Pendidikan dan Pembelajaran (JPP), 20(1), 09-17.

Hambali, M. (2019). Pembelajaran berbasis kehidupan: Konsep dan implementasinya dalam pembelajaran Bahasa Indonesia. Waskita: Jurnal Pendidikan Nilai dan Pembangunan Karakter, 1(1), 129-136. https://doi.org/10.21776/ub.waskita.2017.001.01.8

Mayhew, E. (2018). No longer a silent partner: How mentimeter can enhance teaching and learning within political science. Journal of Political Science Education, 15(4), 1-6. https://doi.org/10.1080/15512169.2018.1538882

Nurhadi, M. A. (1996). Administrasi pendidikan di sekolah. Bandung: Remaja Rosdakarya.

Otoritas Jasa Keuangan. (2017). Survei nasional literasi dan inklusi keuangan 2016 [PowerPoint slides]. https://www.ojk.go.id/id/berita-dan-kegiatan/siaran-pers/Documents/Pages/Siaran-PersOJK-Indeks-Literasi-dan-Inklusi-Keuangan-Meningkat/17.01.23\%20Tayangan\%20\%20 Presscon\%20\%20nett.compressed.pdf

Mulyasa, E. (2011). Menjadi guru profesional: Menciptakan pembelajaran kreatif dan menyenangkan. Bandung: Remaja Rosdakarya.

Pangondian, R. A., Santosa, P. I., \& Nugroho, E. (2019). Faktor-faktor yang mempengaruhi kesuksesan pembelajaran daring dalam revolusi industri 4.0. Seminar Nasional Teknologi Komputer \& Sains (SAINTEKS), 1(1).

Remund, D. L. (2010). Financial literacy explicated: The case for a clearer definition in an increasingly complex economy. Journal of consumer affairs, 44(2), 276-295. https://doi.org/10.1111/j.1745-6606.2010.01169.x

Stannard, R. (2015). Webwatcher. English Teaching Professional 97(67).

Widdowson, D., \& Hailwood, K. (2007). Financial literacy and its role in promoting a sound financial system. Reserve Bank of New Zealand Bulletin, 70(2), 37-47. 